\title{
Performance Evaluation of GFRP Rock Bolt Sensor for Rock Slope Monitoring by Double Shear Test
}

\author{
Jung-Doung Yu, ${ }^{1}$ Jong-Sub Lee $\mathbb{D}^{1},{ }^{1}$ Bibek Tamang $\mathbb{D}^{,}{ }^{2}$ Sungyong Park, ${ }^{3}$ Sukhyun Chang, \\ Jungmyeon Kim, ${ }^{4}$ and Yongseong Kim ${ }^{2}{ }^{2}$ \\ ${ }^{1}$ School of Civil, Environmental, and Architectural Engineering, Korea University, Seoul 02841, Republic of Korea \\ ${ }^{2}$ Department of Regional Infrastructure Engineering, Kangwon National University, Chuncheon 24341, Republic of Korea \\ ${ }^{3}$ Citizens Safety Division, Yongin City Hall, Yongin, Gyeonggi-do 17019, Republic of Korea \\ ${ }^{4}$ Dong Myeong Engineering Consultants \& Architecture, Hwaseong-si, Gyeonggi-do, Republic of Korea
}

Correspondence should be addressed to Yongseong Kim; yskim2@kangwon.ac.kr

Received 12 May 2020; Revised 21 July 2020; Accepted 14 August 2020; Published 29 August 2020

Academic Editor: Jia-wen Zhou

Copyright (c) 2020 Jung-Doung Yu et al. This is an open access article distributed under the Creative Commons Attribution License, which permits unrestricted use, distribution, and reproduction in any medium, provided the original work is properly cited.

\begin{abstract}
This study aims to evaluate the sensing performance of glass fiber-reinforced polymer (GFRP) rock bolt sensors instrumented with strain gauges for monitoring rockslides. Experimental studies are conducted with four different types of GFRP rock bolt sensors and concrete blocks having central holes and two shear joints. Two GFRP rock bolt sensors are inserted into holes and then fixed in concrete blocks with cement grout and soil, respectively. The other two are coated with heat-shrink tubes to protect strain gauges and wires, which are then fixed in concrete blocks with cement grout and soil, respectively. Double shear tests are performed to produce shear deformations of GFRP rock bolt sensors, and then strain change with shear displacement is monitored. The results manifest that the variation in strain with shear displacement is more sensitive in the GFRP rock bolt sensor fixed with soil than with cement grout. Also, strain gauge wires in the GFRP rock bolt sensor fixed with cement grout are broken earlier than with soil. Furthermore, it is confirmed that the heat-shrink tube effectively protects strain gauges and wires, so that GFRP rock bolt sensors coated with heat-shrink tubes work for a longer time than the uncoated sensors. The present study shows that the GFRP rock bolt sensor can be useful for monitoring rock slope failure.
\end{abstract}

\section{Introduction}

Rock bolts are rock reinforcement systems, which are commonly used to stabilize rock slopes [1,2]. Rock slope failures mainly occur in weak rock masses where fractured, laminated, jointed, or discontinued rocks exist $[3,4]$. Rock blots are typically inserted into predrilled holes on rock slopes, and then grout materials are injected into holes. Consequently, rock slopes are reinforced by rock bolts that bind weak rocks together or bind weak rocks to stronger rocks [3]. When rock deformations or rock movements occur, shear or tensile load produced by unstable weak rocks is transferred to rock bolts. If shear or tensile load exceeds the shear or tensile strength of rock bolts, rock bolts will be deformed or failed [5-7]. Li [8,9] have reported that in situ rock bolts observed in fields were deformed or failed due to shear or tensile load caused by rock movements and deformations. It has also been reported that shear deformations of rock bolts were observed in most cases. Recently, theoretical and experimental studies to investigate the rock bolt behavior have been performed. Wu et al. [6] investigated the influence of roughness on the shear behavior of the rock bolt. Their mathematical model demonstrated that the joint roughness strongly affects the shear behavior of the rock bolt. Lee and An [10] performed theoretical and experimental studies on the reinforcing effect of the rock bolt. Therein, the elastic modulus of the jointed rock mass was derived to investigate the reinforcing effects of the rock bolt. They founded that the rock bolt increases the elasticity of the ground and decreases the deflection. Yokota et al. [11] 
investigated the interface behavior between rock bolts and bond materials with shear tests and discontinuous deformation analysis. They reported that shear strength and stiffness increases with an increase in the strength of the mortar.

Significant studies have been conducted to monitor slope displacement or failure. Dowding et al. [12] proposed a method for monitoring rock slopes by measuring electromagnetic signals due to shear and tension of coaxial cables. Chang et al. [13] analyzed the behavior of slope using an optical fiber sensor (OFS) and an inclinometer. Michlmayr et al. [14] monitored slope failure using acoustic signals measured by acoustic emission (AE) sensors. The previous studies have installed a separate sensor to monitor the slope behavior, and no slope monitoring sensor using rock bolts already installed on the slope has been studied until now. Yu et al. $[15,16]$ detected ultrasonic guided waves propagating through the rock bolts using acoustic emission (AE) sensors to evaluate defects in rock bolt grout. Previous studies suggested useful tools for monitoring rock slopes. However, electromagnetic signals are adversely affected by electrical properties of soils such as soil moisture and conductivity resulting in signal attenuation [17]. Commercial optical fiber sensors are effective for monitoring slope displacement, but they become extremely expensive for high-resolution performance [18]. For monitoring slope failure by measuring acoustic signals, high-priced AE sensors should be embedded in the ground. Thus, the objective of this study is to evaluate the performance of the GFRP rock bolt sensor that can monitor rockslide with cost-effective sensors, regardless of signal attenuation due to the electrical properties of soils.

Glass fiber-reinforced polymer (GFRP) has been widely used as a rock bolt due to the ease of cutting, lightweight, low impact of temperature on both strength and stiffness, superior durability, and corrosion resistance $[19,20]$. In this study, the GFRP rock bolt sensor that can play both roles of rockslide prevention and rockslide monitoring is suggested. Besides, the sensing performance of the GFRP rock bolt sensors was evaluated in laboratory experiments. The laboratory experiments were performed with a double shear test, and the strains measured by the GFRP rock bolt sensor due to the shear displacement were analyzed. Cement paste was used to simulate the conditions in which the GFRP rock bolt sensor is grouted to the rock, and it was compared with conditions that the GFRP rock bolt sensors were fixed in concrete blocks with soil. GFRP rock bolts were coated with a heat-shrink tube to protect the GFRP rock bolt sensor, and it was compared with the uncoated case. The remainder of this paper discusses experimental materials and methods, results and discussion for laboratory experiments with double shear tests for the performance evaluation of GFRP rock bolt sensors, and conclusions.

\section{Materials and Methods}

\subsection{Double Shear Test}

2.1.1. Concept of Double Shear Test. Rock bolts reinforce weak rock masses by binding unstable rocks to stable rocks.
If an unstable rock moves coaxially with a rock bolt, an axial load is applied to the rock bolt. If the rock movement is transverse to the rock bolt, the rock bolt will be subjected to a shear load. However, in situ rock bolts are generally subjected to a combination of axial and shear loads that result in a double bend of rock bolt [21]. A single shear test, also known as direct shear test, is a conventional laboratory test to investigate the mechanical behavior of the rock bolt. However, the single shear test cannot induce the double bend of the rock bolt as the single shear test is commonly performed by applying a shear load to the one side of the rock bolt. The double shear tests have been widely used to induce the double bend of the rock bolts [22-25]. The double shear tests are commonly conducted by fixing both sides of the rock bolt and applying a load to the middle of the rock bolt. The double shear test improves the stability of the sample because it does not apply asymmetric shear load. Thus, the double shear test provides more reliable results than the single shear test [26]. It was reported that the single shear test underestimates the shear strength compared with that of the double shear test [27]. In this study, the double shear test was therefore used for evaluating the performance of the GFRP rock bolt sensor.

The double shear test is typically performed with three separate blocks to define two joints as shown in Figure 1(a). Note that a thick nylon sheet or steel plate is placed between concrete blocks during the casing stage. This results in the frictionless and nondilating surface for shear displacement between side and middle concrete blocks. The rock bolt is fully encapsulated with grout materials and then is installed into the concrete blocks. The vertical shear load is only applied to the middle blocks. The top and bottom of two side blocks are fixed while the vertical shear load is applied. This procedure results in two vertical shear planes acting along the rock bolt.

Figure 1(b) shows compression and tensile stresses in the rock bolt under the shear load [28]. The stresses in the upper convex section of the rock bolt are in tension. The stresses in the lower convex section of the rock bolt are in compression. The stresses in the upper concave section of the rock bolt are in compression, while the stresses in the lower concave section are in tension.

2.1.2. Shear Test Apparatus. A double shear test apparatus, as shown in Figure 2, was designed for shearing the GFRP rock bolt sensor. The double shear test apparatus consisted of 6 parts from A to F. The shear apparatus was designed to withstand a load of $500 \mathrm{kN}$. Among the components, the steel plate (A) serves to fix the concrete block (B) to prevent the generation of flexure during the shear load. The steel plate (A) is fixed to the lower plate (D) using the steel bar (E). The steel plate $(\mathrm{C})$ provides space to the concrete block (B) from (D) so that the vertical displacement of the middle concrete block is allowed when sheared. Plate $(F)$ is designed in the form of an I-beam which prevents the plate (D) from deforming due to shear load. Components (A, C, D, E, and F) of the double shear test apparatus were made of stainless steel. 


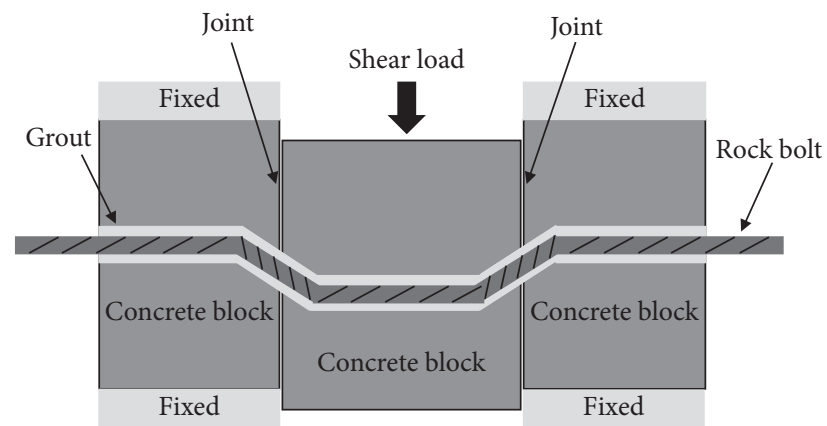

(a)

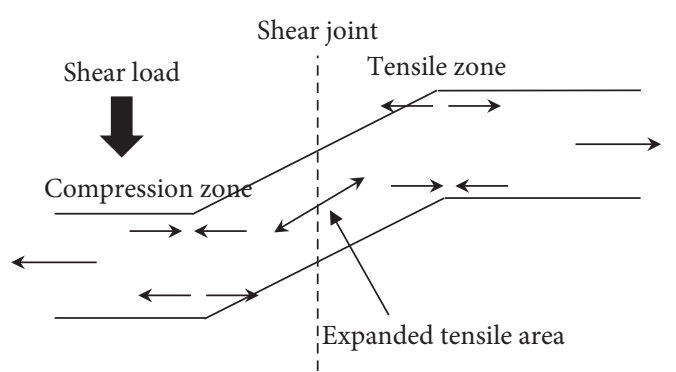

(b)

FIgURE 1: Conceptual illustration of double shear test: (a) double shear test; (b) compression and tensile stresses.

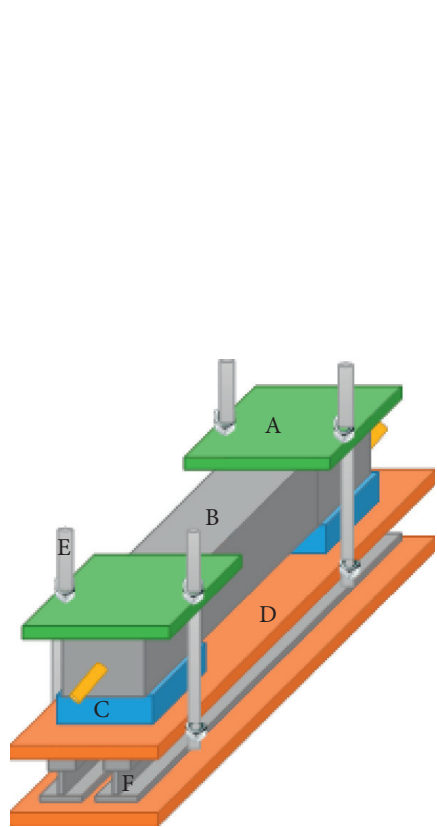

(a)

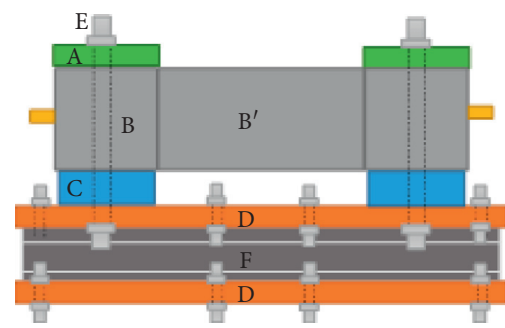

(b)
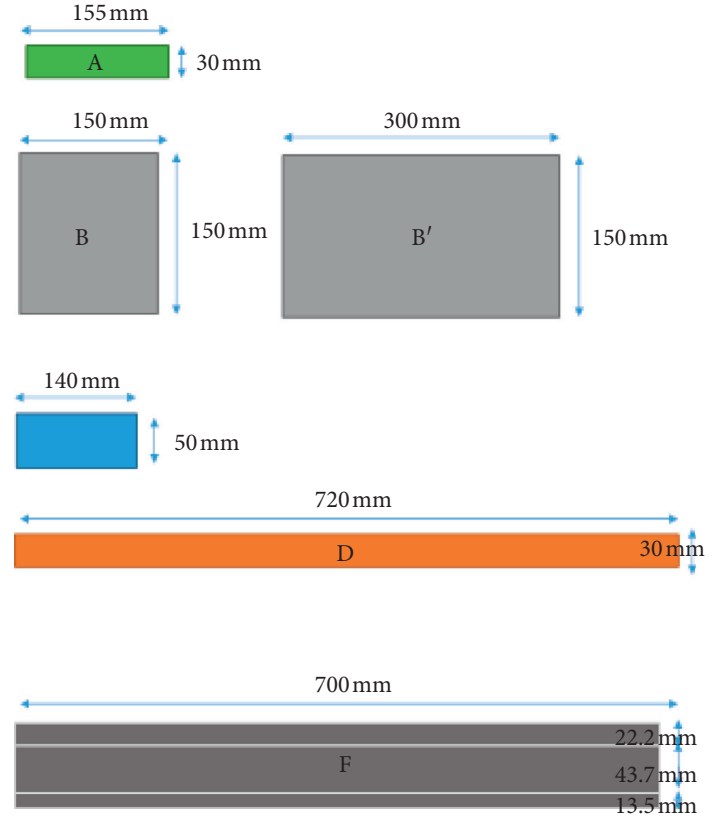

(c)

Figure 2: Double shear test apparatus: (a) isometric view; (b) sectional view; (c) components.

\subsection{Materials}

2.2.1. Glass Fiber-Reinforced Plastic (GFRP). In this study, the GFRP rock bolt sensor was designed using GFPR rock bolt with a diameter of $25 \mathrm{~mm}$ as shown in Figure 3. The uniaxial tensile test was conducted in accordance with ISO 15630-1:2019. Three strain gauges were installed along the GFRP rock bolt surface to measure strains. The surface of the GFRP rock bolt was flattened to attach strain gauges. One strain gauge was placed at the center of the GFRP rock bolt. The other two strain gauges were placed at a distance of $50 \mathrm{~mm}$ from the center of the GFRP rock bolt, respectively. The tensile test was carried out with a displacement rate of $1 \mathrm{~mm} / \mathrm{min}$. The transverse shear test of the GFRP rock bolt was performed with the MTS testing machine as per ASTM D7617-11. The shear load and displacement were measured using a load cell and LVDT, respectively. The displacement rate was set to be $1 \mathrm{~mm} / \mathrm{min}$. The glass fiber content was measured with the combustion test as per ISO 1172:2002. Two test samples were cut from the center of the GFRP rock bolt. The samples were put in crucibles and then heated up to the temperature of $600^{\circ} \mathrm{C}$ for approximately 1 hour. The glass fiber content $\left(M_{\text {glass }}\right)$ in the GFRP rock bolt can be calculated as follows:

$$
M_{\text {glass }}=\frac{m_{3}-m_{1}}{m_{2}-m_{1}} \times 100,
$$

where $m_{1}$ is the initial weight of the dried crucible, $m_{2}$ is the weight of the dried crucible with the dried sample, and $m_{3}$ is the final weight of the dried crucible with calcination residue.

The measured tensile strength, shear strength, and glass fiber content of the GFRP rock bolt are summarized in Table 1 . The tensile strength is $850 \mathrm{MPa}$, the shear strength is $150 \mathrm{MPa}$, and the glass content is $75 \%$. 


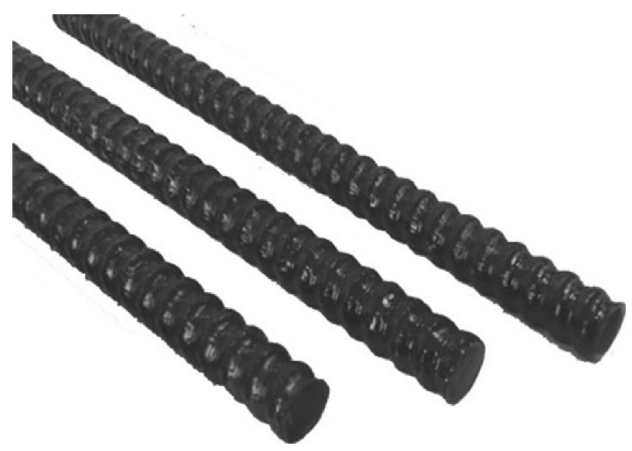

FIGURE 3: Glass fiber-reinforced plastic (GFRP) rock bolt.

2.2.2. Strain Gauge. A strain gauge, as shown in Figure 4, was installed in the GFRP rock bolt for measuring strain. The gauge length and gauge factor of the strain gauge were $5 \mathrm{~mm}$ and 2.11, respectively. The gauge resistance was $118.5 \mathrm{ohm}$ with a strain limit of $5 \%$. The specifications of the strain gauges, used in the study, are summarized in Table 2.

2.2.3. Soil. Soil was used to fix the GFRP rock bolts to the concrete blocks. The soil was silica sand with a particle size of $0.85 \mathrm{~mm}-0.42 \mathrm{~mm}$. The specific gravity of the silica sand was 2.59 , the internal friction angle was $40.5^{\circ}$ at a relative density of $80 \%$, and the maximum and minimum dry densities were $1.62 \mathrm{~g} / \mathrm{cm}^{3}$ and $1.36 \mathrm{~g} / \mathrm{cm}^{3}$, respectively.

2.2.4. Grout. The cement paste was used as grout material to fix the GFRP rock bolts sensor to the concrete blocks. The cement paste was a mixture of cement and water at a weight ratio of $1: 0.5(w / c=0.5)$. Note that water-cement ratio $(w / c)$ in grout materials used for rock bolt systems typically ranged from 0.35 to $0.5[29,30]$. The experiments were performed after the curing period of 30 days.

2.2.5. Concrete. Concrete blocks were constructed with a premixed type concrete (Union HS, Union) to simulate rock mass. The ratio of the weights of water and concrete was $0.12: 1$. The uniaxial compression test was performed with five cylindrical concrete specimens to evaluate the compressive strength as per ASTM C39-18 and ASTM C31-19a. The diameter and length of the specimen were $150 \mathrm{~mm}$ and $300 \mathrm{~mm}$, respectively. The uniaxial compression test was performed after 28 days of curing time. The average compressive strength of five concrete specimens was approximately $80 \mathrm{~N} / \mathrm{mm}^{2}$.

\subsection{Design of GFRP Sensor}

2.3.1. Strain Gauge Installation. The GFPR rock bolts were cut to $0.8 \mathrm{~m}$ in length. The protrusion portion of the GFRP rock bolt was flattened with a grinder to attach a strain gauge, as shown in Figure 5. The flattened portion was smoothed with sandpaper to allow the strain gauge to attach well, as shown in Figure 6. The strain gauge was attached to the smoothened topside of the GFRP rock bolt surface using an adhesive, and then silicone was applied to protect the strain gauge (Figure 7). Four strain gauges were installed at a distance of $5 \mathrm{~cm}$ from the center of the GFRP rock bolt and $175 \mathrm{~mm}$ from both ends (Figure 8).

2.3.2. Coating GFRP Rock Bolt Sensor. The GFRP rock bolt sensor was fully coated with a heat-shrink tube to protect the strain gauge and wires installed in the GFRP rock bolt. The heat-shrink tube used in this study is polyolefin with a diameter of $38 \mathrm{~mm}$, shrinkage temperature of 70 degrees, and longitudinal shrinkage of $5 \%$. The GFRP rock bolt sensor attached with strain gauges was placed inside the heat-shrink tube and heated for the shrinkage as shown in Figure 9.

2.4. Design of Concrete Blocks. The concrete blocks having two shearing surfaces were prepared to simulate a doublejointed rock, as shown in Figure 10. Dimensions of both side concrete blocks were $150 \mathrm{~mm} \times 150 \mathrm{~mm}$ and that of the middle concrete block was $300 \mathrm{~mm} \times 150 \mathrm{~mm}$. In other words, the shearing surface (or joint) was set at a distance of $150 \mathrm{~mm}$ from both ends of concrete blocks. For casting concrete blocks, wooden molds were manufactured as shown in Figure 11. The total internal height, width, and length of the wooden molds were set to be $150 \mathrm{~mm}, 150 \mathrm{~mm}$, and $60 \mathrm{~cm}$, respectively.

Two stainless steel plates with thickness of $1 \mathrm{~mm}$ were installed in the wooden mold to split the concrete block into three blocks by defining two shearing surfaces (i.e., joints) to represent three concrete blocks of the double shear assembly. In order to install a PVC pipe in the wooden mold, holes with a diameter of $40 \mathrm{~mm}$ were drilled at the centers of both side surfaces of the wooden mold and two stainless steel plates. Note that the PVC pipe is removed after casting concrete for inserting the rock bolt into the concrete block. The outer diameter of the PVC pipe was $38 \mathrm{~mm}$, and the PVC pipe was coated with a releasing agent so that the PVC pipe can be easily separated from the concrete. The interfaces between the PVC pipe and both side surfaces of the wooden mold were sealed with hot glue, which is a form of thermoplastic adhesive, to prevent the concrete flowing out.

The concrete was poured into the wooden mold where stainless steel plates and the PVC pipe were installed as shown in Figure 12. The concrete was cured initially in the wooden mold for the first 1 day. Figure 13 shows the curing process of the concrete blocks. After 1 day of curing, the PVC pipe was removed from the concrete by pulling it out, and then the wooden mold was disassembled. The stainless steel plates were finally removed from the concrete resulting in shearing surfaces. The concrete blocks were cured for 28 days. Note that after 1 day of curing, the GFRP rock bolt sensor is installed in the concrete block by inserting the GFRP rock bolt sensor into the central hole of the concrete block. The GFRP rock bolt sensor is finally fixed to the concrete block by filling holes with cement grout or soil. 
TABLE 1: Specifications of GFRP rock bolt.

\begin{tabular}{lccc}
\hline Nominal diameter $(\mathrm{mm})$ & Tensile strength $(\mathrm{MPa})$ & Shear strength $(\mathrm{MPa})$ & Glass content $(\%)$ \\
\hline 25 & 850 & 150 & 75 \\
\hline
\end{tabular}

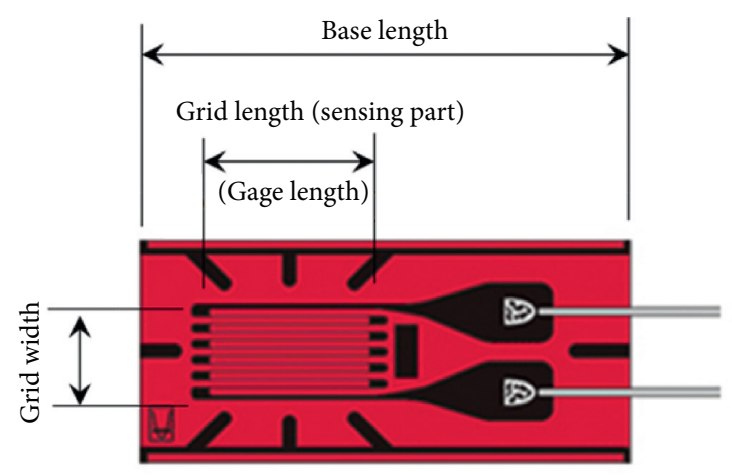

Figure 4: Strain gauge.

TABle 2: Specifications of strain gauge.

\begin{tabular}{lccc}
\hline Gauge Length & Gauge factor & Gauge resistance & Strain limit \\
\hline $5 \mathrm{~mm}$ & 2.11 & $118.5 \Omega$ & $5 \%\left(50000 \times 10^{-6}\right.$ strain $)$ \\
\hline
\end{tabular}

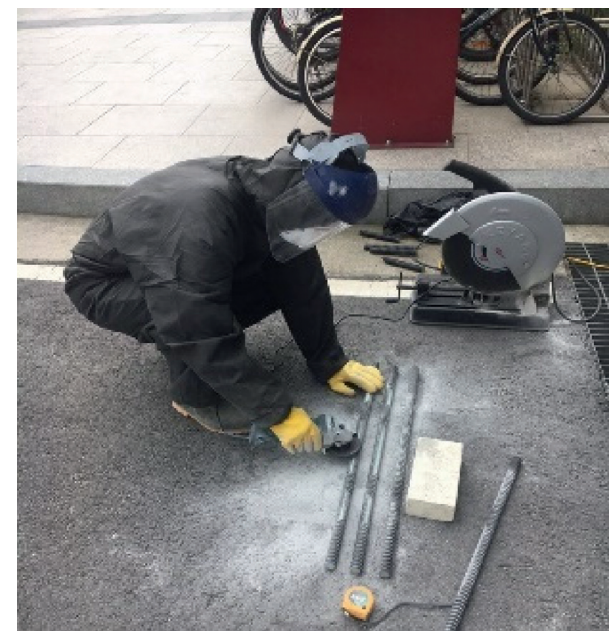

FIGURE 5: Flattening operation for attaching strain gauges.

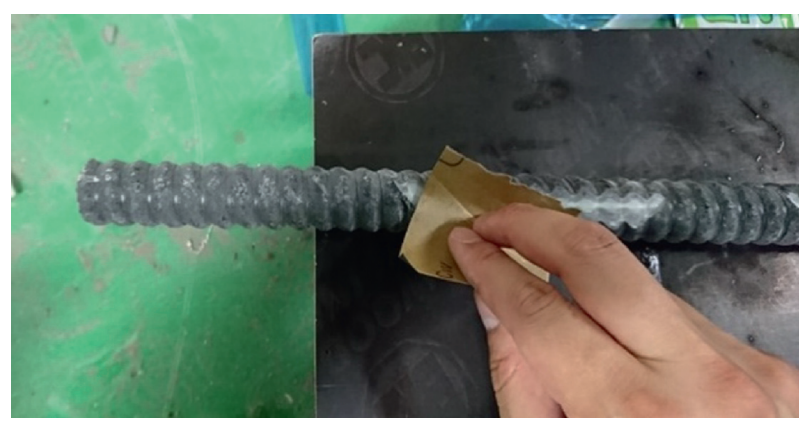

FIgURE 6: Sanding operation for attaching strain gauges.

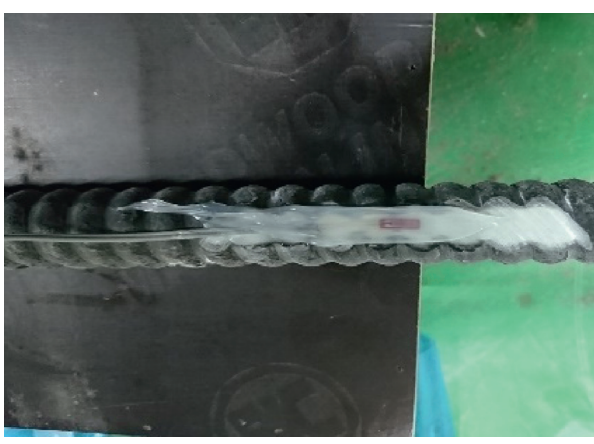

FIGURE 7: Installation of strain gauge.

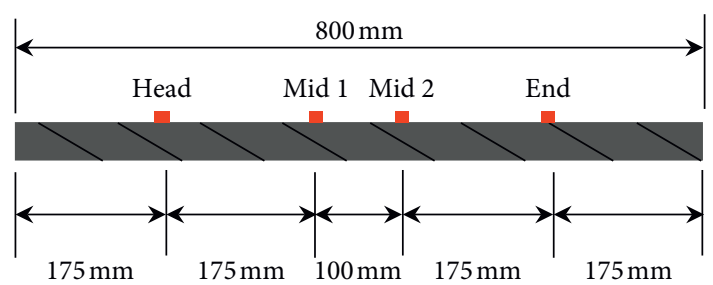

FIGURE 8: Installation position of the strain gauges.

2.5. Installation of GFRP Rock Bolt Sensor. In this study, four types of GFRP rock bolt sensors embedded in concrete blocks were studied as shown in Figure 14. Note that the concrete block is a model of the rock mass. The grout or soil was used to fix the GFRP rock bolt sensor into the concrete block. The heat-shrink tube was used as the coating material to protect sensors. Figure 14(a) shows the GFRP rock bolt sensor fixed 


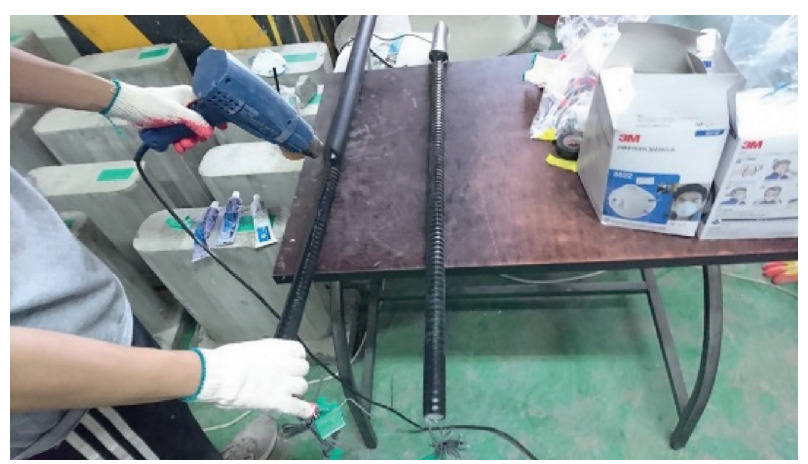

FIGURE 9: Coating GFRP rock bolt sensor with heat-shrink tube.

into the concrete block with cement grout. Figure 14(b) presents the GFRP rock bolt sensor fixed into the concrete block with soil. Figures 14(c) and 14(d) present the GFRP rock bolt sensors coated with a heat-shrink tube for protecting the strain gauge and wires. The two coated GFRP rock bolt sensors are fixed into the concrete block with cement grout and soil, respectively, as shown in Figures 14(c) and 14(d).

\subsubsection{GFRP Sensor Fixed in Concrete Block with Cement} Grout. A donut-shaped styrofoam stopper was installed inside the hole of the concrete block, as shown in Figure 15. A rock bolt was inserted into the styrofoam stopper so that the rock bolt was centered in the hole. As shown in Figure 16, the hot glue was used to fix the rock bolt and prevent the grout from flowing out. Finally, the grout was injected into the hole. The grout material was a cement paste with a $w / c$ ratio of $50 \%$ and was cured in the air for 30 days as described in Section 2.2.4.

2.5.2. GFRP Sensor Fixed in Concrete Block with Soil. Soil was filled into the hole in the concrete block, as shown in Figure 17, to simulate the conditions in which the GFRP rock bolt sensor is fixed to rock mass by soil. The soil was compacted every $2 \mathrm{~cm}$ depth during the filling process. Finally, the end of the concrete block was sealed with glue to prevent the soil from flowing down. The soil was silica sand no. 6 , and it had a particle size of $0.42 \mathrm{~mm}-0.22 \mathrm{~mm}$ as described in Section 2.2.3.

\section{Results and Discussion}

3.1. Experimental Overview. Double shear tests under static loading were conducted with a universal test system (Model 815, MTS Systems Corporation), which has a load capacity of $4600 \mathrm{kN}$, to evaluate sensing performance of four different types of GFRP rock bolt sensors as shown in Figure 18. The GFRP rock bolt sensors embedded in concrete blocks were installed in the double shear apparatus as shown in Figures 2 and 18 . The double shear test apparatus was placed between the upper and lower grip of the universal test system. The load cell was mounted on the lower grip. The vertical upward load was then applied to the double shear apparatus at a constant displacement rate of $0.5 \mathrm{~mm} / \mathrm{min}$. Both side blocks installed in the double shear test apparatus remained fixed as the middle concrete block was pushed down resulting. The middle concrete block, therefore, moved in vertically downward direction resulting in the shear displacement as shown in Figure 19. The shear load, displacement, and strain were measured every second using the data logger and recorded using the computer.

\subsection{Experiment Results}

\subsubsection{Uncoated GFRP Rock Bolt Sensor Fixed with Grout}

(1) Strain vs. Shear Displacement. The double shear tests were carried carried out on uncoated GFRP rock bolt senor fixed into the concrete block with the cement grout. The strain due to the shear displacement measured at the head and endpoints of the GFRP rock bolt sensor is plotted in Figure 20(a). As shown, the strain values at the head and endpoints are almost the same. The strain increases linearly up to the displacement of $3 \mathrm{~mm}$ and again increases linearly from the shear displacement of $3 \mathrm{~mm}$ to $6 \mathrm{~mm}$. The presence of two linear sections is caused by the failure of cement grout due to shear displacement. As the shear deformation of the GFRP rock bolt sensor increases, the grout is crushed causing a reduction of the bonding strength between the grouted rock bolt and the concrete block. This results in the strain to be more sensitive to the shear displacement. The nonlinear behavior of the strain appears after the displacement of $6 \mathrm{~mm}$. The strain gradually increases as the shear displacement increases from $6 \mathrm{~mm}$ to $7 \mathrm{~mm}$ in displacement. After the displacement of $7 \mathrm{~mm}$, the strain changes insignificantly. Strain gauge wires in the GFRP rock bolt sensor were broken at $8 \mathrm{~mm}$ in the displacement.

The relationship between the stain and shear displacement at midpoints is plotted in Figure 20(b). The measured strain due to the shear displacement at midpoint 1 is almost the same as that at midpoint 2. At the midpoint 2, the strain increases linearly up to about $1 \mathrm{~mm}$ in displacement. The strain was not measured after approximately $1.1 \mathrm{~mm}$ in the displacement due to the gauge wire breakage. The strain gauge wires located at the midpoints 1 and 2 broke earlier than the strain gauge wires at the head and endpoints without nonlinear behavior. This is because the stresses in the rock bolt embedded in the middle concrete are in compression. Note that the shear load was applied to the middle concrete block by resulting in the shear displacement in the vertical direction.

\subsubsection{Coated GFRP Rock Bolt Sensor Fixed with Grout}

(1) Overview. If the GFRP rock bolt sensor is fixed to the rock with the cement grout, strain gauges and wires can be damaged during rock displacement because the GFRP rock bolt sensor is directly contacted with the cement grout. In this study, GFRP rock bolt sensors, therefore, were coated with heat-shrink tubes to protect the strain gauges and wires. The coated GFRP rock bolts were inserted into the concrete blocks and then fixed with the cement grout. Double shear tests were performed on the coated GFRP rock bolt sensor fixed with grout. 


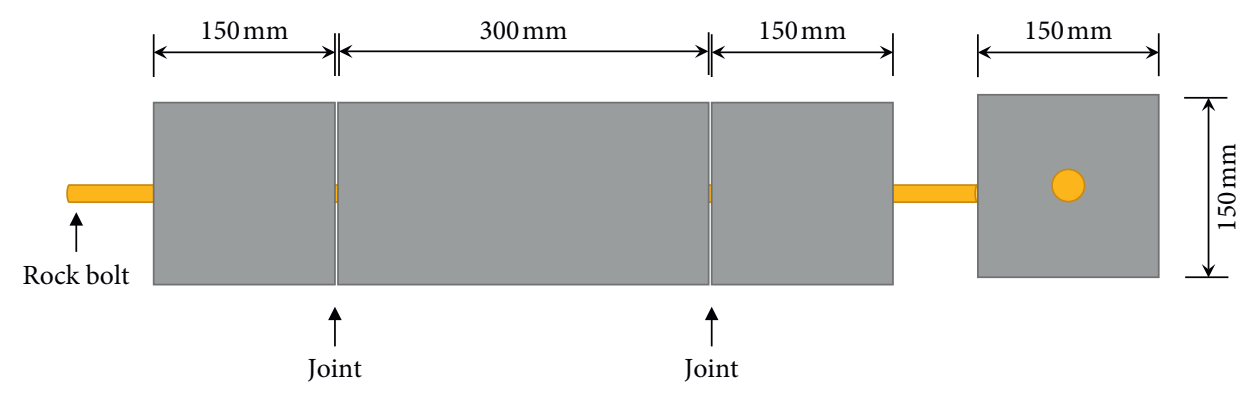

(a)

(b)

Figure 10: Rock bolt embedded in double-jointed concrete block: (a) side view; (b) front view.

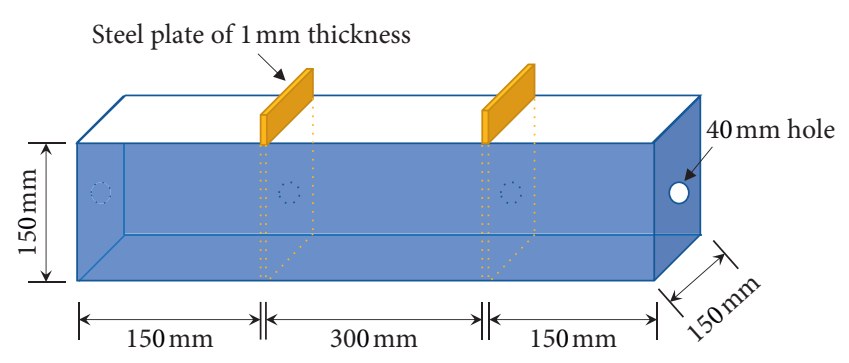

Figure 11: Wooden mold for casting concrete blocks.

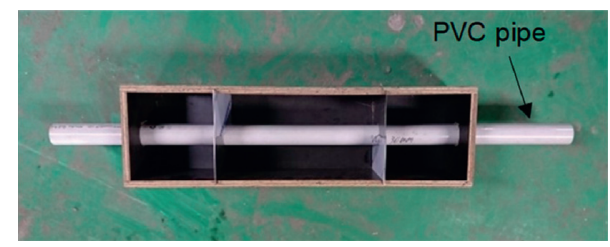

Figure 12: Wooden mold with PVC pipe.

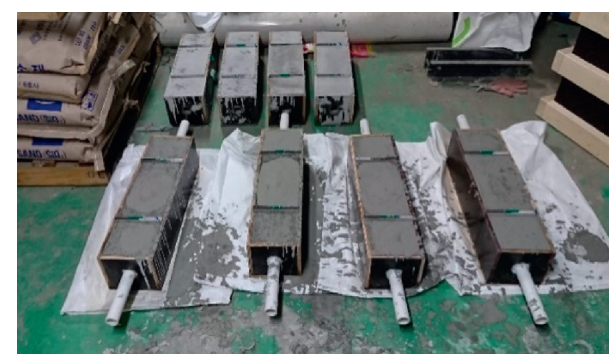

Figure 13: Curing process of concrete blocks.

(2) Strain vs. Shear Displacement. The measured strain due to the shear displacement for the coated GFRP rock bolt sensor fixed with grout is plotted in Figure 21. As shown, the measured strains at the head and endpoints are almost similar. The strain increases linearly until the shear displacement of about $3 \mathrm{~mm}$, at which the strain is about $1,200 \times 10^{-6}$. Afterward, the strain gradually increases with an increase in the shear displacement. In other words, the nonlinear behavior appears after $3 \mathrm{~mm}$ in displacement owing to the rock bolt yielding. The yielding begins slightly earlier comparing that the nonlinear behavior of the rock bolt usually appears between $3 \mathrm{~mm}$ and $6 \mathrm{~mm}$ in displacement [28]. This is because the coating reduces the bonding strength between the grouted rock bolt and the concrete block. The strain gauge wire was broken when the shear displacement reached about $9 \mathrm{~mm}$, at which the strain was about $2,000 \times 10^{-6}$.

As shown in Figure 21, the variation in strain due to the shear displacements at midpoints 1 and 2 is almost the same. The strains due to the shear displacement at the midpoints are almost the same as those at the head and endpoints before approximately $1 \mathrm{~mm}$ in the displacement. Afterward, the strains due to the shear displacement at the head and endpoints, however, are larger than those at midpoints. This is because the stresses in the rock bolt embedded in the middle concrete are in compression, while those in both side concrete blocks are in tension. The strain gauges located at midpoints 1 and 2 were broken earlier compared with those at head and endpoints. This is because that the GFRP rock bolt embedded in the middle concrete block was subjected to the shear load resulting in the shear displacement in the vertical direction.

(3) Comparison of Strain-Shear Displacement Relationship between Uncoated and Coated GFRP Rock Bolt Sensors Fixed with Grout. The variation in strain due to the shear displacement measured in the uncoated GFRP rock bolt sensor fixed with grout is compared with that measured in the coated GFRP rock bolt sensor fixed with grout in Figure 22. Figures 22(a) and 22(b) show the variation in strain due to the shear displacement at head and endpoints and midpoints, respectively. As shown in Figure 22(a), strains in the coated GFRP rock bolt sensor are measured up to $9 \mathrm{~mm}$ in displacement. However, strains in the uncoated GFRP rock bolt sensor are measured up to $8 \mathrm{~mm}$ in displacement. In other words, strain gauge wires in the coated GFRP rock bolt sensor were broken earlier compared with those in the uncoated GFRP rock bolt sensor. This observation also appears in Figure 22(b). Strains at midpoints 1 and 2 in the uncoated GFRP rock bolt sensor are measured up to $1.7 \mathrm{~mm}$ and $1.1 \mathrm{~mm}$ in displacement, respectively. However, strains at midpoints 1 and 2 in the coated GFRP rock bolt sensor are measured up to $3.7 \mathrm{~mm}$ and $3.2 \mathrm{~mm}$ in displacement, respectively, which are approximately $2 \mathrm{~mm}$ longer compared with the uncoated GFRP rock bolt sensor. This is because the heat-shrink tube protects strain gauges and wires from 


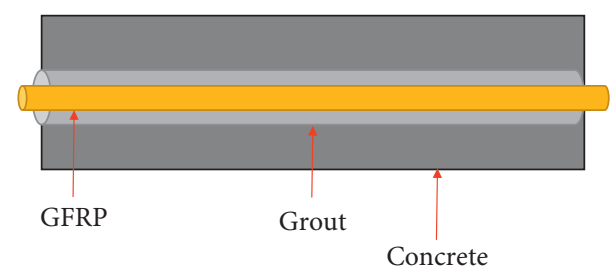

(a)

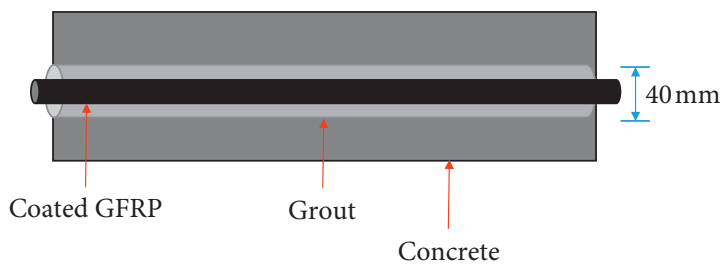

(c)

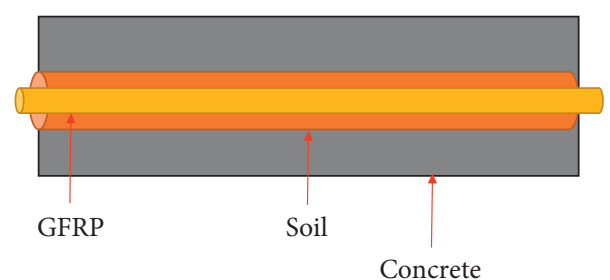

(b)

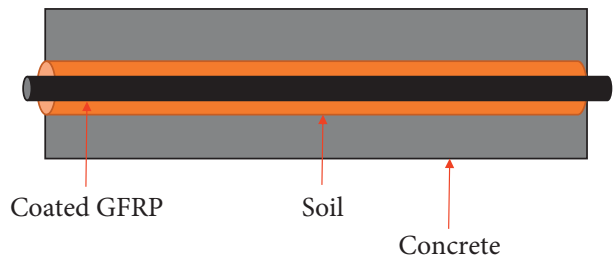

(d)

FIGURE 14: Four different types of GFRP rock bolt sensors: (a) fixed with cement grout without coating; (b) fixed with soil without coating; (c) fixed with cement grout with coating; (d) fixed with soil with coating.

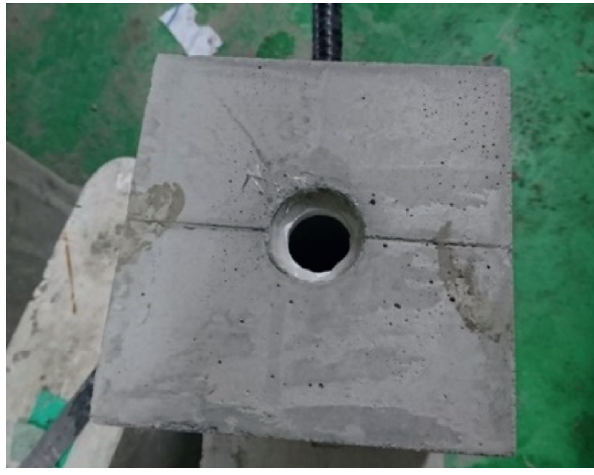

FIGURE 15: Styrofoam stopper for inserting rock bolt and injecting grout.

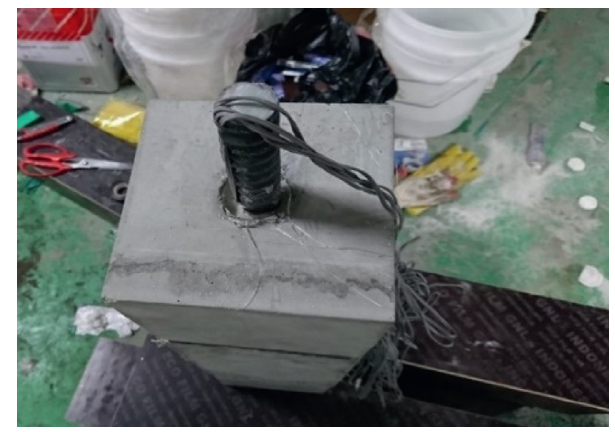

FIGURE 16: Finishing work by glue gun.

damages. This demonstrates that the heat-shrink tube effectively protects strain gauges and wires in the coated GFRP rock bolt sensor. Note that in the case of the uncoated GFRP rock bolt sensor, strain gauges and wires were directly contacted with the cement grout. Thus, strain gauges and wires are susceptible to damages under shear deformation of the uncoated GFRP rock bolt sensor.
The strain measured in the coated GFRP rock bolt sensor at displacement between $0 \mathrm{~mm}$ and $4 \mathrm{~mm}$ is greater than that in the uncoated GFRP rock bolt sensor. In other words, the coated GFRP rock bolt sensor is more sensitive than the uncoated rock bolt sensor at displacement between $0 \mathrm{~mm}$ and $4 \mathrm{~mm}$. However, the strain measured in the coated GFRP rock bolt sensor is smaller than that in the uncoated GFRP rock bolt sensor after displacement of $4 \mathrm{~mm}$. This is because the bonding strength much significantly affects the variation in the strain after the grout fracture. Note that the bonding strength in uncoated is greater than that in the coated rock bolt because the heat-shrink tube reduces the friction between the cement grout and rock bolt. Also, ribs of the rock bolt play a crucial role in increasing friction [31]. However, the heatshrink tube may adversely affect the function of ribs.

\subsubsection{Uncoated GFRP Rock Bolt Sensor Fixed with Soil}

(1) Overview. Rock bolts are generally grouted using cement paste to be fixed into rock. However, this study also evaluated the sensing performance of GFRP rock bolt sensors fixed into concrete blocks with the soil. The sensing performance of GFRP rock bolt sensors fixed with the soil was compared with that fixed with grout. The soil used in this study was silica with a particle size of $0.42 \mathrm{~mm}$ to $0.22 \mathrm{~mm}$.

(2) Strain vs. Shear Displacement. Figure 23 shows the strain due to the shear displacement measured in the uncoated GFRP rock bolt sensor fixed with soil. As shown, the strain due to shear displacement at the head point is almost the same as that at the endpoint. The strains at head and endpoints linearly increase up to about $9 \mathrm{~mm}$ in displacement, at which the strains are approximately $15,000 \times 10^{-6}$ and $14,000 \times 10^{-6}$, respectively. Afterward, the strain gradually decreases with the increasing shear displacement, and the strain is not accurately measured after displacement of $12 \mathrm{~mm}$. In other words, the nonlinear stage appears after $12 \mathrm{~mm}$ in displacement owing to the rock bolt yielding. Note that the nonlinear stage of the rock 


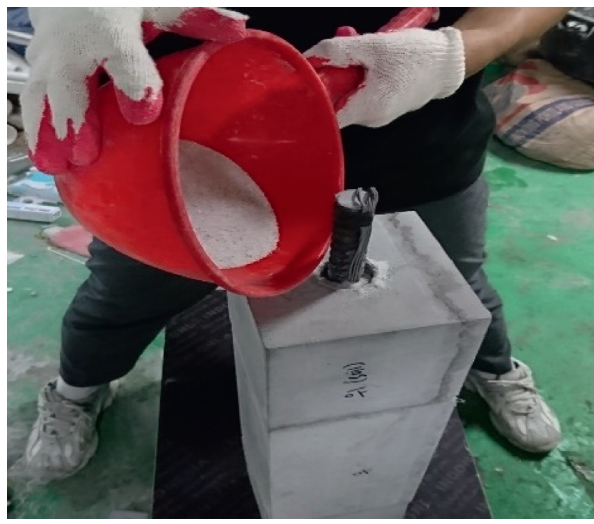

(a)

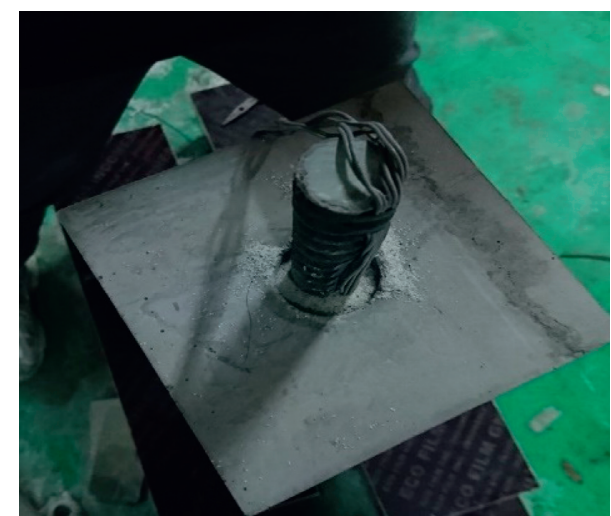

(b)

FIGURE 17: Installation of GFRP rock bolt sensor fixed with soil: (a) filling sand; (b) concrete block completely filled with sand.

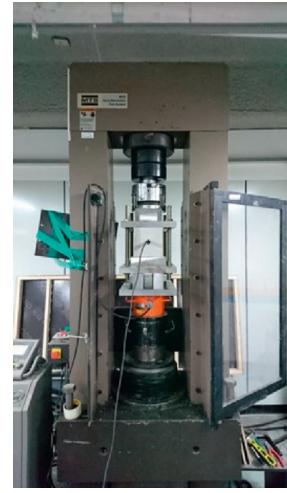

(a)

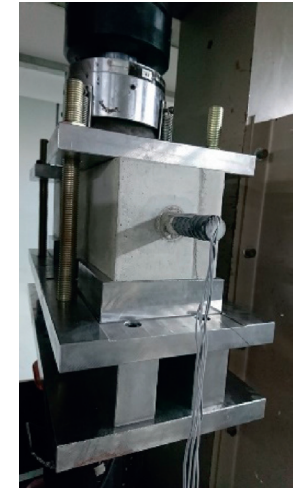

(b)

Figure 18: Shear test: (a) uniaxial compression tester; (b) double shear apparatus.

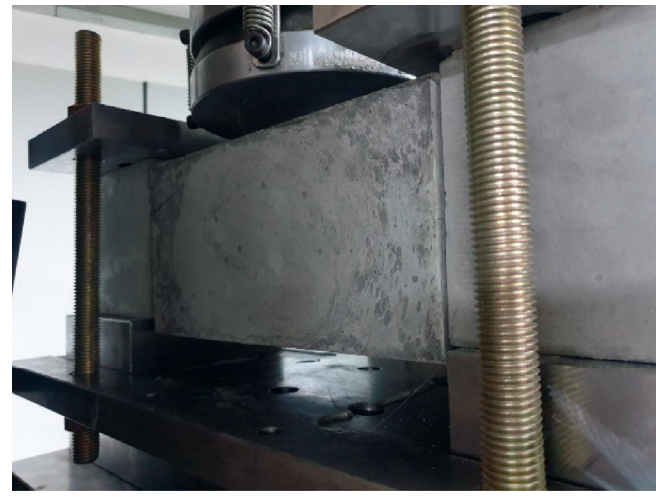

FIGURE 19: Shear planes of concrete block.

bolt fixed with cement grout typically is usually the range of $3 \mathrm{~mm}$ and $6 \mathrm{~mm} \mathrm{[28],} \mathrm{which} \mathrm{is} \mathrm{larger} \mathrm{than} \mathrm{the} \mathrm{nonlinear} \mathrm{stage}$ observed in the uncoated GFRP rock bolt sensor fixed with soil. This is because the friction between the rock bolt and soil is smaller than that between the rock bolt and the cement grout. Note that the coefficient of friction between GFRP rock bolt and cement grout is typically 0.7 [32]. The coefficient of friction between GFRP rock bolt and soil is in the range of 0.3 and 0.5
[33]. The bonding strength caused by chemical reactions between rock bolt and cement grout also increases the resistance of the rock bolt subjected to shear load [34, 35]. Thus, more sensitive variation in the strain appears in the uncoated GFRP rock bolt sensor fixed with soil compared with a conventional GFRP rock bolt fixed with cement grout. The strain gauge wires were completely broken after displacement of $16 \mathrm{~mm}$.

The strains at the midpoints 1 and 2 show almost identical values up to a shear displacement of $6 \mathrm{~mm}$. Afterward, the nonlinear stage in strain is observed after the displacement of $9 \mathrm{~mm}$. The strain gauge wires were completely broken at the displacement of $12 \mathrm{~mm}$. The strains measured at the head and endpoint are greater than those at midpoints 1 and 2. This is because the stresses in the rock bolt embedded in the middle concrete are in compression, while those in both side concrete blocks are in tension.

(3) Comparison of Strain-Shear Displacement Relationship between Uncoated GFRP Rock Bolt Sensors Fixed with Grout and Soil. The strain due to the shear displacement in the uncoated GFRP rock bolt sensor fixed with cement grout is compared with that in the uncoated GFRP rock bolt fixed with soil in Figures 24 and 25. Figures 24 and 25 show the 


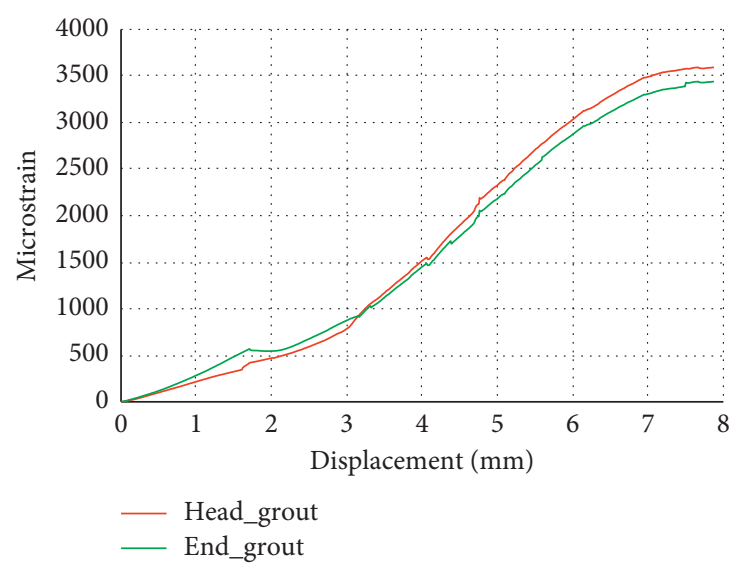

(a)

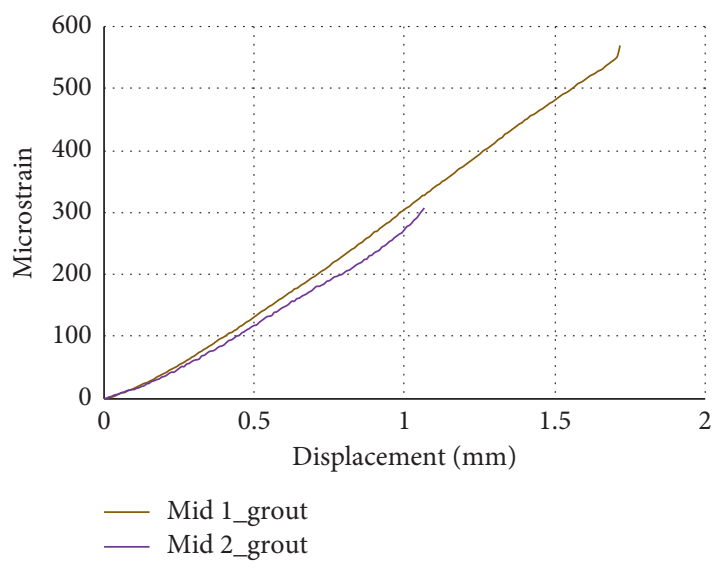

(b)

FIGURE 20: Strain vs. displacement for uncoated GFRP rock bolt sensor fixed with grout at (a) head and endpoints and (b) midpoints.

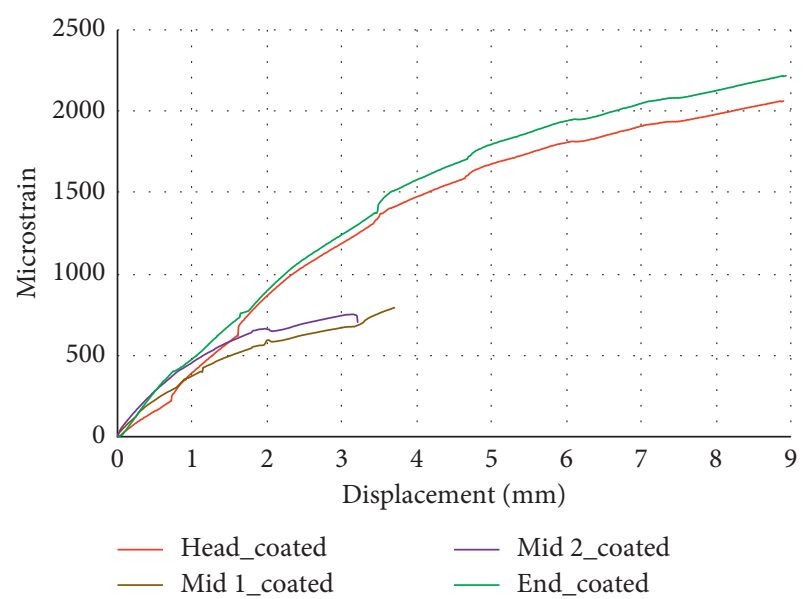

Figure 21: Strain vs. displacement for coated GFRP rock bolt sensor fixed with grout.

variation in strain due to the shear displacement at head and endpoints and midpoints, respectively. As shown in Figure 24, the strain at head and endpoints in the uncoated GFRP rock bolt fixed with soil is about $6,000 \times 10^{-6}$ at the shear displacement of $4 \mathrm{~mm}$. On the other hand, the strain at head and endpoints in the uncoated GFRP rock bolt sensor fixed with cement grout is less than $2,000 \times 10^{-6}$, i.e., difference of about 3 times. In other words, the strain is more sensitive to shear displacement when the uncoated GFRP rock bolt sensor is fixed with soil compared with that fixed with grout. This is because the friction between the grout and the uncoated GFRP rock bolt sensor is greater compared with the friction between the soil and the uncoated GFRP rock bolt sensor. Furthermore, the bonding strength between the uncoated GFRP rock bolt sensor and grout may adversely affect the variation in the strain. The strain is measured up to about $10 \mathrm{~mm}$ displacement for the uncoated GFRP rock bolt sensor fixed with soil, whereas the strain is measured up to about $8 \mathrm{~mm}$ displacement for the uncoated rock bolt sensor fixed with grout. This is because that strain gauge wires are strongly bonded to the grout compared with that of the soil.
As shown in Figure 25, the strain at midpoints in the uncoated GFRP rock bolt sensor fixed with soil is about $2,000 \times 10^{-6}$ at the displacement of $2 \mathrm{~mm}$. This is about three times larger than the strain of $650 \times 10^{-6}$ at the displacement of $2 \mathrm{~mm}$ in the uncoated GFRP rock bolt sensor fixed with grout. The strain variation in the GFRP rock bolt sensor fixed with soil is more sensitive compared with the GFRP rock bolt sensor fixed with grout. The strain measurement was possible till shear displacement of $10 \mathrm{~mm}$ for the uncoated GFRP rock bolt sensor fixed with soil. However, when the GFRP rock bolt sensor was fixed with the grout, the strain measurement was possible until the shear displacement of $3.5 \mathrm{~mm}$. This is because that strain gauge wires are strongly bonded to the grout compared with that with the soil.

\subsubsection{Coated GFRP Rock Bolt Sensor Fixed with Soil}

(1) Overview. In Figure 22, it has been shown that a coated GFRP rock bolt sensor fixed with grout is capable of measuring strain up to a larger shear displacement compared to the uncoated one. Also, as shown in Figures 24 and 25 , the uncoated GFRP rock bolt sensor fixed with soil is more sensitive to the variation in strain compared to that fixed with grout. In this study, a GFRP rock bolt sensor, therefore, was coated with a heat-shrink tube and fixed with soil to protect the strain gauge and wires and to increase sensing sensitivity. The sensing performance of the coated GFRP rock bolt sensor fixed with soil was compared with that of the other three different types of GFRP rock bolt sensors (uncoated GFRP rock bolt sensor fixed with grout, coated GFRP rock bolt sensor fixed with grout, and uncoated GFRP rock bolt sensor fixed soil).

(2) Strain-Shear Displacement. For the coated GFRP rock bolt sensor fixed with soil, the variation in the strain due to the shear displacement measured at the head and points and midpoints is plotted in Figure 26. As shown, the strain due to shear displacement at the head point is almost the same as that at the endpoint. The strains linearly increase up to approximately $12 \mathrm{~mm}$ and $13 \mathrm{~mm}$ of displacement in the 


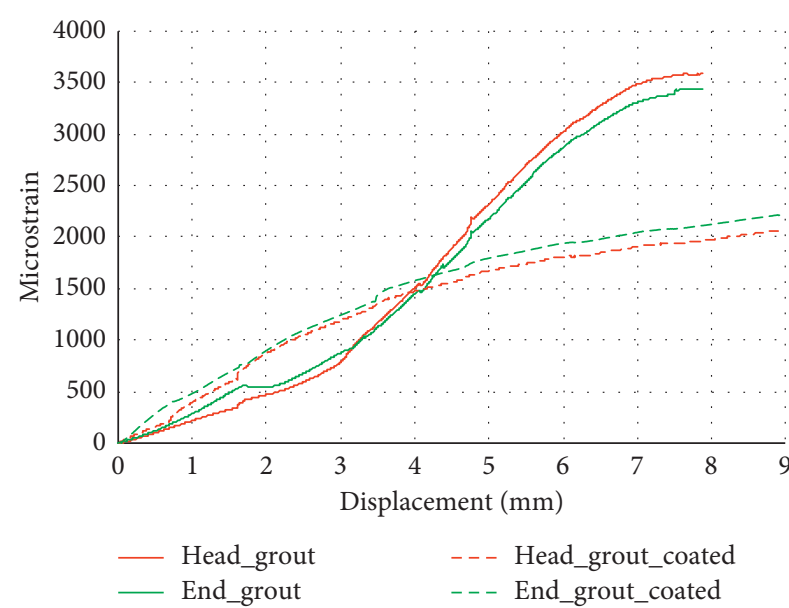

(a)

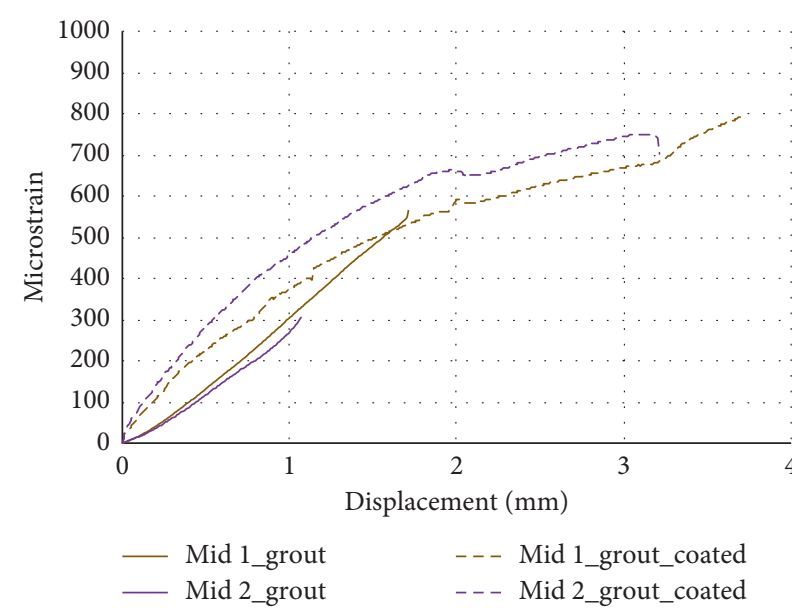

(b)

FIGURE 22: Strain vs. displacement for coated and uncoated GFRP rock bolt sensors fixed with grout at (a) head and endpoints and (b) midpoints.

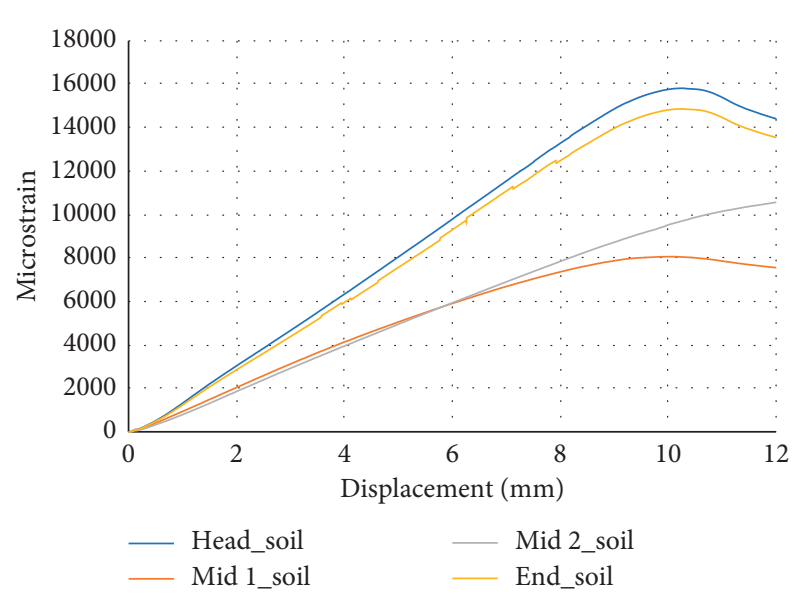

FIGURE 23: Strain vs. displacement for GFRP rock bolt sensor fixed with soil.

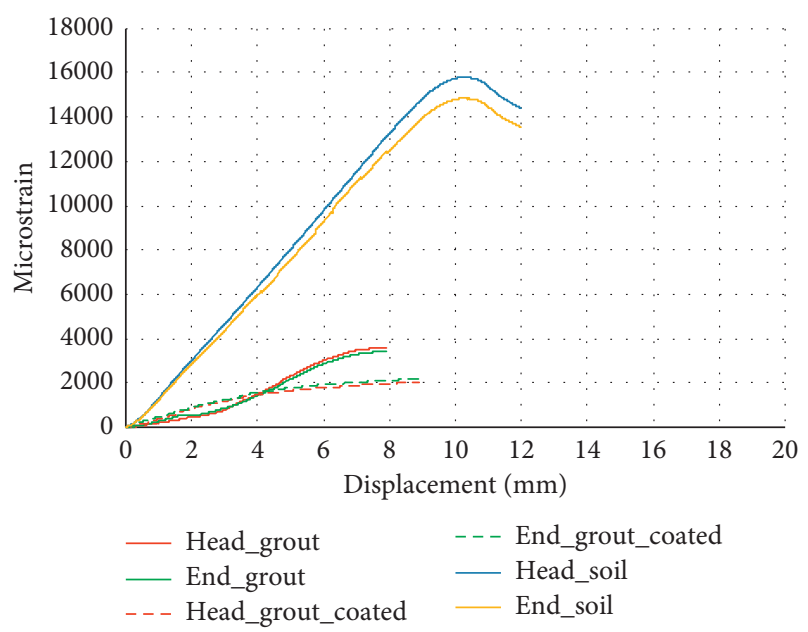

Figure 24: Strain vs. displacement at head and endpoints for uncoated GFRP rock bolt sensors fixed with grout and soil and coated GFRP rock bolt sensor fixed with grout.

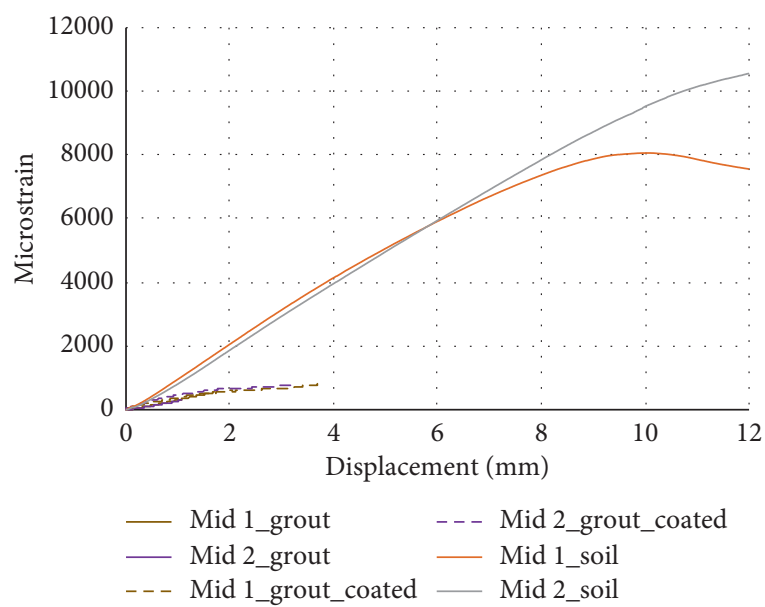

FIGURE 25: Strain vs. displacement at midpoints for uncoated GFRP rock bolt sensors fixed with grout and soil and coated GFRP rock bolt sensor fixed with grout.

head and endpoints of the coated GFRP rock bolt sensor fixed with soil, respectively. Afterward, the strain gradually decreases with increasing shear displacement. In the case of the head point, the strain was not accurately measured after about $14 \mathrm{~mm}$ of shear displacement, and the wires were broken at a displacement of about $16 \mathrm{~mm}$. Similarly, the strain was able to be measured until $15 \mathrm{~mm}$ in the endpoint, and the wires were broken at a displacement of about $21 \mathrm{~mm}$.

For midpoints 1 and 2, the linear relationship between the strain and shear displacement appears, as shown in Figure 26. As shown, the strain due to shear displacement at midpoint 1 is almost the same as that at midpoint 2 . The strain at midpoint 1 increases linearly up to the shear displacement of $11 \mathrm{~mm}$ while the strain at midpoint 2 increases linearly up to the shear displacement of $12 \mathrm{~mm}$. Afterwards, strain gauge wires were broken completely. The strains measured at the head and endpoint are greater than those at midpoints 1 and 2. This is because the stresses in the rock 


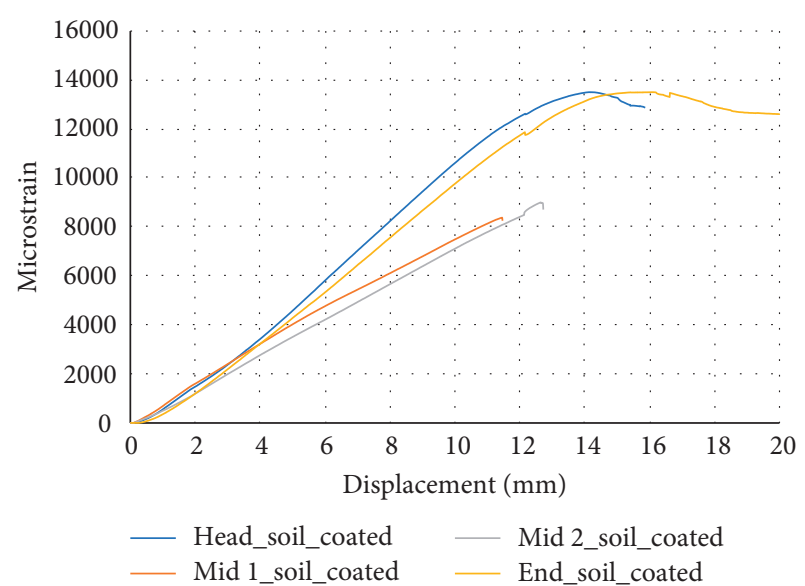

FIGURE 26: Strain vs. displacement for coated GFRP rock bolt sensor fixed with soil.

bolt embedded in the middle concrete are in compression, while those in both side concrete blocks are in tension.

(3) Comparison of Strain-Shear Displacement Relationship between Uncoated and Coated GFRP Rock Bolt Sensors Fixed with Soil. As shown in Figure 27, the strain at the head and endpoints of four different types of the GFRP rock bolt sensors (coated and uncoated GFRP rock bolt sensors fixed with soil and coated and uncoated GFRP rock bolt sensors fixed with grout) is compared. It is observed that the strain measured in the coated GFRP rock bolt sensor fixed with soil is smaller compared with that in the uncoated GFPR rock bolt sensor fixed with soil. At $8 \mathrm{~mm}$ of shear displacement, the strain measured in the coated GFRP rock bolt sensor fixed with soil is about $8,000 \times 10^{-6}$, which is about 1.6 times smaller compared with the strain $\left(13,000 \times 10^{-6}\right)$ measured in the uncoated GFRP rock bolt sensor fixed with soil. This is due to the reduction of the friction between rock bolt and soil owing to the heat-shrink tube. However, strain measurement was possible up to the displacement of $13 \mathrm{~mm}$ to $15 \mathrm{~mm}$ for the coated GFRP rock bolt sensor fixed with soil. This is greater than the uncoated GFRP rock bolt sensor fixed with soil, which was capable of measuring strain only up to the shear displacement of $9 \mathrm{~mm}$. This is because the heat-shrink tube protects the strain gauge and wires. The coating effect is also observed in the coated GFRP rock bolt sensor fixed with grout. In addition, even when the coated GFRP rock bolt sensor is fixed with soil, the greater sensing sensitivity can be seen compared with the coated and uncoated GFRP rock bolt sensors fixed with grout.

Figure 28 shows the strain due to the shear displacement in the midpoints of the four different types of GFRP rock bolt sensors. Similar to the strain in head and endpoints, the strain in midpoints of the coated GFRP rock bolt sensor fixed with soil is observed to be smaller compared with that of the uncoated GFRP rock bolt sensor fixed with soil. At midpoints 1 and 2, the strains in the coated GFRP rock bolt sensor fixed with soil are $4,200 \times 10^{-6}$ and $4,800 \times 10^{-6}$ at the displacement of $5 \mathrm{~mm}$, respectively. However, strains at midpoints 1 and 2 in the uncoated GFRP rock bolt sensor

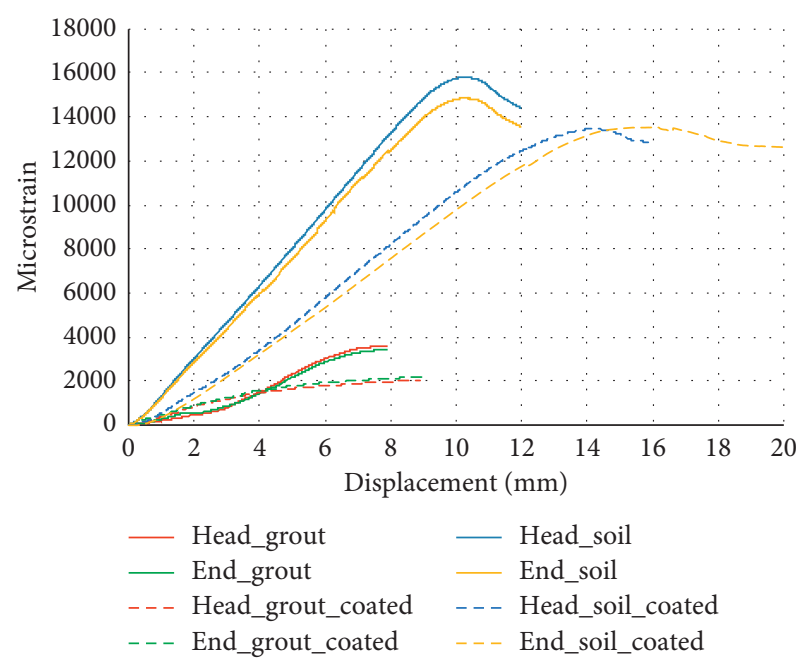

FIgURE 27: Strain vs. displacement at head and endpoints for uncoated and coated GFRP rock bolt sensors.

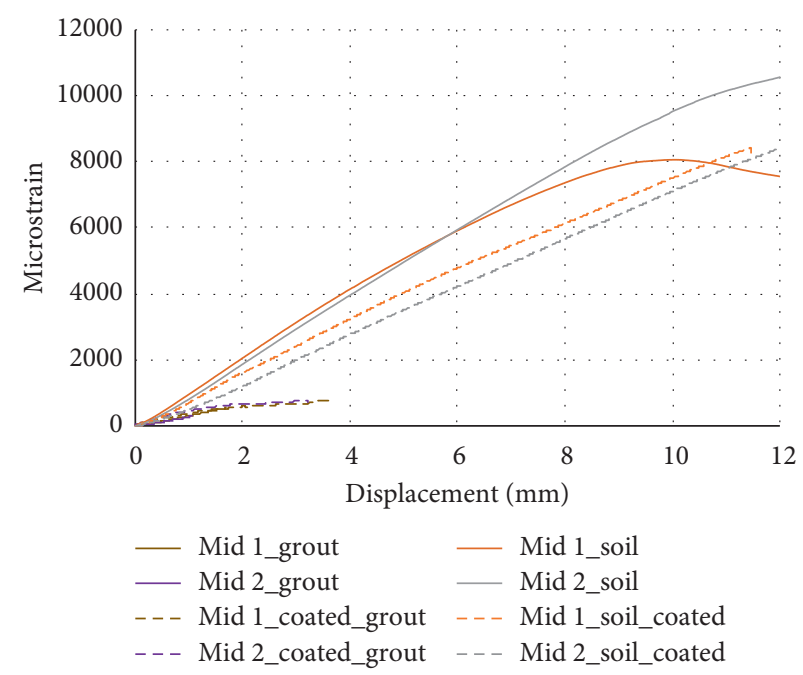

FIgURE 28: Strain vs. displacement at midpoints for coated and uncoated GFRP rock bolt sensors.

fixed with soil are about $70 \%$ and $80 \%$ of the strains in the coated GFRP rock bolt sensor fixed with soil, respectively. This is because that the heat-shrink tube reduces the friction between the coated GFRP rock bolt sensor and soil.

\section{Conclusions}

Double shear tests were performed on coated and uncoated GFRP rock bolt sensors fixed with cement grout and soil to evaluate the performance of the GFRP rock bolt sensor. The conclusions of the study are as follows:

(1) The measured strain due to shear displacement was less sensitive in case of the GFRP rock bolt sensor coated with heat-shrink tube fixed with cement grout than that of uncoated one. However, in case of grouted GFRP rock bolt sensor, the damage phenomenon of the strain gauge gets reduced as the rock 
bolt sensor deforms, allowing strain gauge in measuring greater shear displacement.

(2) In case of GFRP rock bolt sensor fixed with soil, greater variation in strain was observed compared with the one fixed with cement grout. In addition, it was able to measure the strain due to greater shear displacement compared with the GFRP rock bolt sensor fixed with the cement grout. This shows that fixing the GFRP rock bolt sensor with soil resulted in less damage to the strain gauge than fixing with cement grout.

(3) The coated GFRP rock bolt sensor fixed with soil was less sensitive to shear displacement than the uncoated GFRP rock bolt sensor. However, the strain could be measured even at larger shear displacements. This shows that the heat-shrink tube is effective in protecting the GFRP rock bolt sensor.

(4) For the coated GFRP rock bolt sensor fixed into the concrete block with soil, it is found that the variation in strain shows good sensitivity to shear displacement. In addition, the strain was measured even at larger shear deformation. This type of GFRP rock bolt sensor could be considered as a more efficient type compared with the other three types of GFRP rock bolt sensor.

\section{Data Availability}

The excel data used to support the findings of this study are available from the corresponding author upon request.

\section{Conflicts of Interest}

The authors declare that there are no conflicts of interest regarding the publication of this article.

\section{Acknowledgments}

This work was supported by the Korea Institute of Planning and Evaluation for Technology in Food, Agriculture, Forestry and Fisheries (IPET) through the Advanced Production Technology Development Program, funded by Ministry of Agriculture, Food and Rural Affairs (MAFRA) (11611403).

\section{Supplementary Materials}

The raw data for the coated and uncoated GFRP rock bolt sensors fixed with grout and soil are given in the supplementary material file. (Supplementary Materials)

\section{References}

[1] T. A. Lang and J. A. Bischoff, "Stabilization of rock excavations using rock reinforcement," International Journal of Rock Mechanics and Mining Sciences \& Geomechanics Abstracts, vol. 20, no. 3, 1983.

[2] Y. Chen, "Experimental study and stress analysis of rock bolt anchorage performance," Journal of Rock Mechanics and Geotechnical Engineering, vol. 6, no. 5, pp. 428-437, 2014.
[3] X. B. Li, Z. L. Zhou, Q. Y. Li, and L. Q. Hu, "Parameter analysis of anchor bolt support for large-span and jointed rock mass," Journal of Central South University, vol. 12, no. 4, pp. 483-487, 2005.

[4] R. K. Panigrahi, "Rock fracture studies for hill rock slope," in Proceedings of the in Rock Mechanics and its Applications in Civil, Mining, and Petroleum Engineering, pp. 126-135, American Society of Civil Engineers, Shanghai, China, May 2014.

[5] J. Nemcik, S. Ma, N. Aziz, T. Ren, and X. Geng, "Numerical modelling of failure propagation in fully grouted rock bolts subjected to tensile load," International Journal of Rock Mechanics and Mining Sciences, vol. 71, pp. 293-300, 2014.

[6] X. Wu, Y. Jiang, and B. Li, "Influence of joint roughness on the shear behaviour of fully encapsulated rock bolt," Rock Mechanics and Rock Engineering, vol. 51, no. 3, pp. 953-959, 2018.

[7] H. Jalalifar, "An assessment of load transfer mechanism using the instrumented bolts," in Proceedings of the Coal Operators' Conference, pp. 255-265, Wollongong, Australia, 2006.

[8] C. C. Li, "Field observations of rock bolts in high stress rock masses," Rock Mechanics and Rock Engineering, vol. 43, no. 4, pp. 491-496, 2010.

[9] B. P. Simser, "The weakest link—-ground support observations at some Canadian shield hard rock mines," in Proceedings of the 4th International Seminar on Deep and High Stress Mining, pp. 7-9, Perth, Australia, 2007.

[10] H. S. An and S. D. Lee, "Reinforcing effects of bolting in jointed rock mass," International Journal of Geo-Engineering, vol. 7, 2016.

[11] Y. Yokota, Z. Zhao, W. Nie, K. Date, K. Iwano, and Y. Okada, "Experimental and numerical study on the interface behaviour between the rock bolt and bond material," Rock Mechanics and Rock Engineering, vol. 52, no. 3, pp. 869-879, 2019.

[12] C. H. Dowding, M. B. Su, and K. O’Connors, "Principles of time domain reflectometometry applied to measurement of rock mass deformation," International Journal of Rock Mechanics and Mining Sciences \& Geomechanics Abstracts, vol. 25, no. 5, pp. 287-297, 1988.

[13] K. T. Chang, H. S. Han, and B. S. Yoo, "Analysis of slope behavior using FBG sensor and inclinometer," Journal of the Korean Geotechnical Society, vol. 19, pp. 397-406, 2003.

[14] G. Michlmayr, A. Chalari, A. Clarke, and D. Or, "Fiber-optic high-resolution acoustic emission (AE) monitoring of slope failure," Landslides, vol. 14, no. 3, pp. 1139-1146, 2017.

[15] J.-D. Yu, Y.-H. Byun, and J.-S. Lee, "Experimental and numerical studies on group velocity of ultrasonic guided waves in rock bolts with different grouted ratios," Computers and Geotechnics, vol. 114, Article ID 103130, 2019.

[16] J.-D. Yu, M.-H. Bae, I.-M. Lee, and J.-S. Lee, "Nongrouted ratio evaluation of rock bolts by reflection of guided ultrasonic waves," Journal of Geotechnical and Geoenvironmental Engineering, vol. 139, no. 2, pp. 298-307, 2013.

[17] J. S. Lee and J. D. Yu, "Non-destructive method for evaluating grouted ratio of soil nail using electromagnetic wave," Journal of Nondestructive Evaluation, vol. 38, no. 2, 2019.

[18] C. A. R. Díaz, C. A. F. Marques, M. F. F. Domingues et al., “A cost-effective edge-filter based FBG interrogator using catastrophic fuse effect micro-cavity interferometers," Measurement, vol. 124, pp. 486-493, 2018.

[19] A. Littlejohn, "A review of glass fibre reinforced polymer (GFRP) tendon for rock bolting in tunnels," in Proceedings of the Institution of Civil Engineers-International Conference on 
Ground Anchorages and Anchored Structures in Service, pp. 177-187, London, UK, 2007.

[20] M. B. Hovgaard, Performance of Fully Grouted GFRP Rock Bolt in Combined Pull and Shear, Norwegian University of Science and Technology, Trondheim, Norway, 2019.

[21] B. Forbes, N. Vlachopoulos, A. J. Hyett, and M. S. Diederichs, "A new optical sensing technique for monitoring shear of rock bolts," Tunnelling and Underground Space Technology, vol. 66, pp. 34-46, 2017.

[22] N. Aziz, P. Damian, and R. Williams, "Double shear testing of bolts," in Proceedings of the Coal Operators' Conference, pp. 154-161, Wollongong, NSW, Australia, 2003.

[23] G. Grasselli, "3D behaviour of bolted rock joints: experimental and numerical study," International Journal of Rock Mechanics and Mining Sciences, vol. 42, no. 1, 2005.

[24] A. Hyett, B. Forbes, and S. Spearing, "Enlightening bolts: using distributed optical sensing to measure the strain profile along fully grouted rock bolts," in Proceedings of the 32nd International Conference on Ground Control in Mining, pp. 107-112, Morgantown, WA, USA, 2013.

[25] H. Jalalifar and N. Aziz, "Analytical behaviour of bolt-joint intersection under lateral loading conditions," Rock Mechanics and Rock Engineering, vol. 43, no. 1, pp. 89-94, 2010.

[26] L. Li, P. C. Hagan, S. Saydam, and B. Hebblewhite, "Shear resistance contribution of support systems in double shear test," Tunnelling and Underground Space Technology, vol. 56, pp. 168-175, 2016.

[27] N. Aziz, A. Mirzaghorbanali, J. Nemcik, K. Heemann, and S. Mayer, "Shear strength properties of plain and spirally profiled cable bolts," Canadian Geotechnical Journal, vol. 52, no. 10, pp. 1490-1495, 2015.

[28] H. Jalalifar, N. Aziz, and M. N. Hadi, "Rock and bolt properties and load transfer mechanism in ground reinforcement," in Proceedings of the 20th World Mining Congress 2005, Mining and Sustainable Development, Theran, Iran, pp. 629-635, 2005.

[29] A. Kilic, E. Yasar, and A. G. Celik, "Effect of grout properties on the pull-out load capacity of fully grouted rock bolt," Tunnelling and Underground Space Technology, vol. 17, no. 4, pp. 355-362, 2002.

[30] M. Moosavi and W. F. Bawden, "Shear strength of portland cement grout," Cement and Concrete Composites, vol. 25, no. 7, pp. 729-735, 2003.

[31] A. A. Almusallam, S. A. Al-Gahtani, and A. R. Aziz, "Rasheeduzzafar effect of reinforcement corrosion on bond behaviour," Construction and Building Materials, vol. 10, no. 2, p. 129, 1996.

[32] M. Mesbah, R. Benzaid, and B. Benmokrane, "Evaluation of bond strength of FRP reinforcing rods in concrete and FE modelling," International Journal of Civil Engineering, vol. 4, pp. 21-41, 2017.

[33] J. D. Frost and J. Han, "Behavior of interfaces between fiberreinforced polymers and sands," Journal of Geotechnical and Geoenvironmental Engineering, vol. 125, no. 8, pp. 633-640, 1999.

[34] E. Cosenza, G. Manfredi, and R. Realfonzo, "Behavior and modeling of bond of FRP rebars to concrete," Journal of Composites for Construction, vol. 1, no. 2, pp. 40-51, 1997.

[35] S. Yu, W. Zhu, L. Niu, S. Zhou, and P. Kang, "Experimental and numerical analysis of fully grouted long rockbolt loadtransfer behavior," Tunnelling and Underground Space Technology, vol. 85, pp. 56-66, 2019. 